\title{
Fatty acid composition of the tissues of Coregonus lavaretus $L$. of the Kola Peninsula
}

\author{
Lyudmila A. Mishanina ${ }^{1, *}$ and Anna V. Malaeva ${ }^{2}$ \\ ${ }^{1}$ Associate professor, candidate of biological Sciences, Murmansk State Technical University, 183010, str. Sportivnaya, 13, Murmansk, \\ Russia \\ ${ }^{2}$ Associate professor, candidate of pedagogics, Murmansk State Technical University, 183010, str. Sportivnaya, 13, Murmansk, Russia
}

\begin{abstract}
The study reveals the results of the analysis of fatty acid composition of muscle, liver and gonad tissues of the whitefish Coregonus lavaretus L. of different ages from lakes Lovozero and Umbozero of the Kola Peninsula. The analysis of fatty acid composition in organs and tissues allows to evaluate the physiological characteristics of the organism. It was found that the content of monoenoic fatty acids in the muscles of the whitefish from lake Lovozero is higher than that of the whitefish from Umbozero. It is probably due to the features of the food base of the objects studied. In the muscles of immature whitefish of lake Umbozero the content of polyenic fatty acids is higher compared to the fish from Lovozero. The content of PUFA significantly increases in the mature whitefish from Umbozero lake perhaps due to the temperature regime in water bodies and different rates of motor activity of fish. Lower levels of PUFA in the liver of the whitefish from Lovozero lake may indicate reduced metabolism in hepatocytes. In the gonads of female whitefish from the studied water bodies, the content of saturated fatty acids is low compared to the polyene fatty acids which is characteristic for the viscosity reduction in the membranes of oocytes.
\end{abstract}

\section{Introduction}

A significant criterion for evaluating the physiological state of fish is the analysis of fatty acid composition. During the first years of life cycle, fatty acid composition of tissues and organs changes, ensuring the adaptation of fish to the environmental changes.

The increased content of polyenic fatty acids in lipids, unlike monoenic and saturated, is related with the increase in the level of fish mobility, as well as decrease in temperature of the environment. Fatty acids provide the integrity of cell membranes and determine membrane permeability, the activity of membrane-bound enzymes [1].

The study analyzes fatty acid composition of muscle tissue, liver and gonads of females of a valuable commercial species - whitefish Coregonus lavaretus L. from Lovozero and Umbozero Lakes of the Kola Peninsula.

\section{Methods and equipment}

The object of study is whitefish Coregonus lavaretus L. from lakes Lovozero and Umbozero of the Kola Peninsulas at the age of $3+$ (pre-mature) and 5+ (mature).

The material for analysis is muscle and liver tissues $(3+$ and $5+)$ and gonads of female whitefish $(5+)$. The whitefish were caught in late June - early July. Samples for analysis consisted of tissue or organ samples taken from 3 samples of the same age.

Total lipids were extracted from the tissues and organs by Bligh-Dyer method [2]. After direct transesterification of lipids in methanol [3] methyl esters of fatty acids were separated using gas-liquid chromatograph "Chromatec Crystal - 5000.1" (Russia). Polyethylene glycol adipate ( $15 \%$ ) was the liquid phase, helium was the gas carrier, its flow rate was $30 \mathrm{ml} / \mathrm{min}$. Behenic acid (22:0) was used as an internal standard for the identification of fatty acids.

Using generally accepted methods with probability belief $p \leq 0.05$, statistical processing of the measurement results was performed [4].

\section{Results and discussion}

The main components of the fatty acid (FA) pool in the whitefish from Lovozero and Umbozero lakes are palmitic, stearic, palmitoleic, oleic, linoleic, linolenic, arachidonic, eicosapentaenoic and docosahexaenoic acids (Tables 1,2).

\footnotetext{
Corresponding author: ludapoh@yandex.ru
} 
Table 1. Fatty acid composition of the whitefish Coregonus lavaretus L. from lake Lovozero of the Kola Peninsula, \% of total FA.

\begin{tabular}{|c|c|c|c|c|c|}
\hline \multirow{2}{*}{$\begin{array}{l}\text { Fatty } \\
\text { acids }\end{array}$} & \multicolumn{2}{|c|}{$3+$} & \multicolumn{3}{|c|}{$5+$} \\
\hline & muscles & liver & muscles & liver & $\begin{array}{c}\text { gonads } \\
q\end{array}$ \\
\hline 14:0 & $2,3 \pm 0,1$ & $3,1 \pm 0,2$ & $2,4 \pm 0,1$ & $3,3 \pm 0,2$ & $1.7 \pm 0.1$ \\
\hline 15:0 & $0,9 \pm 0,1$ & $0,9 \pm 0,1$ & $0,9 \pm 0,1$ & $1,1 \pm 0,1$ & $1.1 \pm 0.1$ \\
\hline 16:0 & $24,2 \pm 1,1$ & $\begin{array}{c}15,6 \pm 1 \\
0\end{array}$ & $\begin{array}{c}22,7 \pm 1 \\
2\end{array}$ & $\begin{array}{c}15,8 \pm 1 \\
0\end{array}$ & $7.4 \pm 0.5$ \\
\hline $16: 1$ & $9,4 \pm 0,4$ & $\begin{array}{c}13,8 \pm 0 \\
8\end{array}$ & $9,8 \pm 0,4$ & $\begin{array}{c}14,0 \pm 1 \\
0\end{array}$ & $\begin{array}{c}14.5 \pm 0 \\
5\end{array}$ \\
\hline 17:0 & $1,2 \pm 0,1$ & $3,2 \pm 0,1$ & $1,4 \pm 0,1$ & $3,4 \pm 0,2$ & $2.7 \pm 0.1$ \\
\hline 18:0 & $8,6 \pm 0,3$ & $8,4 \pm 0,3$ & $8,5 \pm 0,4$ & $9,2 \pm 0,4$ & $3.4 \pm 0.3$ \\
\hline 18:1 & $16,7 \pm 1,2$ & $\begin{array}{c}20,8 \pm 1 \\
2\end{array}$ & $\begin{array}{c}18,8 \pm 1 \\
1\end{array}$ & $\begin{array}{c}19,8 \pm 1 \\
1\end{array}$ & $\begin{array}{c}13.3 \pm 1 . \\
2\end{array}$ \\
\hline $18: 2(n-6)$ & $4,3 \pm 0,3$ & $1,9 \pm 0,1$ & $3,5 \pm 0,2$ & $2,3 \pm 0,1$ & $4.6 \pm 0.2$ \\
\hline $18: 3(n-3)$ & $5,3 \pm 0,3$ & $2,7 \pm 0,2$ & $4,4 \pm 0,2$ & $3,1 \pm 0,2$ & $6.4 \pm 0.3$ \\
\hline $20: 1$ & $5,2 \pm 0,3$ & $7,5 \pm 0,3$ & $6,2 \pm 0,3$ & $8,1 \pm 0,3$ & $6.2 \pm 0.3$ \\
\hline $20: 2(n-6)$ & $1,3 \pm 0,1$ & $1,1 \pm 0,1$ & $1,4 \pm 0,1$ & $1,2 \pm 0,1$ & $1.2 \pm 0.1$ \\
\hline $20: 3(n-6)$ & $1,2 \pm 0,1$ & $1,3 \pm 0,1$ & $1,3 \pm 0,1$ & $1,4 \pm 0,1$ & $1.1 \pm 0.1$ \\
\hline $20: 4(n-6)$ & $6,1 \pm 0,3$ & $6,2 \pm 0,3$ & $5,1 \pm 0,3$ & $5,6 \pm 0,3$ & $6.3 \pm 0.4$ \\
\hline $20: 5(n-3)$ & $4,1 \pm 0,3$ & $4,6 \pm 0,3$ & $4,8 \pm 0,2$ & $3,7 \pm 0,2$ & $\begin{array}{c}12.3 \pm 0 \\
5\end{array}$ \\
\hline $22: 5(n-3)$ & $1,3 \pm 0,1$ & $1,4 \pm 0,1$ & $1,2 \pm 0,1$ & $1,3 \pm 0,1$ & $2.5 \pm 0.1$ \\
\hline $22: 6(n-3)$ & $6,5 \pm 0,3$ & $5,3 \pm 0,3$ & $6,1 \pm 0,3$ & $4,7 \pm 0,2$ & $\begin{array}{c}13.6 \pm 1 \\
1\end{array}$ \\
\hline Other** & $1,4 \pm 0,1$ & $2,2 \pm 0,1$ & $1,5 \pm 0,1$ & $2,0 \pm 0,1$ & $1.7 \pm 0.1$ \\
\hline \multicolumn{6}{|l|}{ Total } \\
\hline $\begin{array}{l}\text { saturated, } \\
\%\end{array}$ & $37,2 \pm 1,7$ & $\begin{array}{c}31,2 \pm 1 \\
7\end{array}$ & $\begin{array}{c}35,9 \pm 1 \\
9\end{array}$ & $\begin{array}{c}32,8 \pm 1 \\
9\end{array}$ & $\begin{array}{c}16.3 \pm 1 . \\
1\end{array}$ \\
\hline $\begin{array}{l}\text { monoenic } \\
, \%\end{array}$ & $32,7 \pm 2,0$ & $\begin{array}{c}44,3 \pm 2 \\
2 \\
\end{array}$ & $\begin{array}{c}36,3 \pm 1 \\
9\end{array}$ & $\begin{array}{c}43,9 \pm 2 \\
4\end{array}$ & $\begin{array}{c}35.7 \pm 2 . \\
1\end{array}$ \\
\hline $\begin{array}{l}\text { polyenic } \\
, \% \\
\end{array}$ & $30,1 \pm 2,2$ & $\begin{array}{c}24,5 \pm 1 \\
5 \\
\end{array}$ & $\begin{array}{c}27,8 \pm 1, \\
5 \\
\end{array}$ & $\begin{array}{c}23,3 \pm 1 \\
6 \\
\end{array}$ & $\begin{array}{c}48.0 \pm 1 . \\
8\end{array}$ \\
\hline$(n-6), \%$ & $12,9 \pm 1,1$ & $\begin{array}{c}10,5 \pm 0 \\
6\end{array}$ & $\begin{array}{c}11,3 \pm 0 \\
7\end{array}$ & $\begin{array}{c}10,5 \pm 0 \\
6\end{array}$ & $\begin{array}{c}13.2 \pm 1 \\
1\end{array}$ \\
\hline
\end{tabular}

\begin{tabular}{|l|c|c|c|c|c|}
\hline $\mathbf{( n - 3 ) , \%}$ & $17,2 \pm 1,0$ & $\begin{array}{c}14,0 \pm 0, \\
9\end{array}$ & $\begin{array}{c}16,5 \pm 0, \\
8\end{array}$ & $\begin{array}{c}12,8 \pm 0, \\
7\end{array}$ & $\begin{array}{c}34.8 \pm 2 . \\
0\end{array}$ \\
\hline$(\mathrm{n}-3) /(\mathrm{n}-6)$ & 1,33 & 1,33 & 1,46 & 1,22 & 2.64 \\
\hline $\begin{array}{l}18: 3(\mathrm{n}-3) \\
/ 18: 2(\mathrm{n}-6)\end{array}$ & 1,23 & 1,42 & 1,26 & 1,35 & 1.39 \\
\hline
\end{tabular}

** - 14:1, 15:1, 16:1, 17:1

Table 2. Fatty acid composition of the whitefish Coregonus lavaretus L. from lake Umbozero of the Kola Peninsula, \% of total FA.

\begin{tabular}{|c|c|c|c|c|c|}
\hline \multirow{2}{*}{$\begin{array}{l}\text { Fatty } \\
\text { acids }\end{array}$} & \multicolumn{2}{|c|}{$3+$} & \multicolumn{3}{|c|}{$5+$} \\
\hline & muscles & liver & muscles & liver & $\begin{array}{c}\text { gonads } \\
q\end{array}$ \\
\hline 14:0 & $2,2 \pm 0,1$ & $2,0 \pm 0,1$ & $1,1 \pm 0,1$ & $1,8 \pm 0,1$ & $1.6 \pm 0.1$ \\
\hline 15:0 & $0,7 \pm 0,1$ & $0,4 \pm 0,1$ & $0,4 \pm 0,1$ & $0,5 \pm 0,1$ & $0.8 \pm 0.1$ \\
\hline 16:0 & $22,1 \pm 1,1$ & $9,7 \pm 0,5$ & $\begin{array}{c}14,8 \pm 1 \\
0 \\
\end{array}$ & $8,4 \pm 0,5$ & $6.5 \pm 0.5$ \\
\hline $16: 1$ & $7,5 \pm 0,3$ & $9,6 \pm 0,5$ & $7,3 \pm 0,3$ & $8,2 \pm 0,5$ & $\begin{array}{l}13.2 \pm 0 . \\
5\end{array}$ \\
\hline $17: 0$ & $1,1 \pm 0,1$ & $2,3 \pm 0,1$ & $0,5 \pm 0,1$ & $2,1 \pm 0,1$ & $2.5 \pm 0.1$ \\
\hline 18:0 & $7,3 \pm 0,3$ & $5,4 \pm 0,3$ & $4,4 \pm 0,2$ & $3,5 \pm 0,3$ & $2.8 \pm 0.3$ \\
\hline $18: 1$ & $15,2 \pm 1,2$ & $\begin{array}{c}18,3 \pm 1 \\
2\end{array}$ & $\begin{array}{c}16,4 \pm 1 \\
1\end{array}$ & $\begin{array}{c}17,1 \pm 1 \\
2\end{array}$ & $\begin{array}{l}13.1 \pm 1 . \\
2\end{array}$ \\
\hline $18: 2(n-6)$ & $4,8 \pm 0,3$ & $2,7 \pm 0,2$ & $6,8 \pm 0,3$ & $4,0 \pm 0,2$ & $4.8 \pm 0.2$ \\
\hline $18: 3(n-3)$ & $6,2 \pm 0,3$ & $4,1 \pm 0,3$ & $\begin{array}{c}10,4 \pm 0 \\
8 \\
\end{array}$ & $7,4 \pm 0,3$ & $6.6 \pm 0.3$ \\
\hline $20: 1$ & $3,3 \pm 0,1$ & $5,6 \pm 0,3$ & $2,3 \pm 0,2$ & $3,8 \pm 0,3$ & $5.9 \pm 0.3$ \\
\hline $20: 2(n-6)$ & $1,2 \pm 0,1$ & $1,5 \pm 0,1$ & $1,7 \pm 0,1$ & $1,9 \pm 0,1$ & $1.6 \pm 0.1$ \\
\hline $20: 3(n-6)$ & $1,4 \pm 0,1$ & $1,1 \pm 0,1$ & $1,6 \pm 0,1$ & $1,2 \pm 0,1$ & $1.3 \pm 0.1$ \\
\hline $20: 4(n-6)$ & $9,3 \pm 0,5$ & $8,5 \pm 0,4$ & $9,5 \pm 0,6$ & $7,6 \pm 0,4$ & $6.7 \pm 0.5$ \\
\hline $20: 5(n-3)$ & $5,1 \pm 0,3$ & $\begin{array}{c}10,3 \pm 0 \\
5\end{array}$ & $7,1 \pm 0,4$ & $\begin{array}{c}12,2 \pm 0 \\
5\end{array}$ & $\begin{array}{l}13.4 \pm 0 . \\
5\end{array}$ \\
\hline $22: 5(n-3)$ & $1,9 \pm 0,1$ & $2,7 \pm 0,1$ & $2,2 \pm 0,1$ & $2,9 \pm 0,1$ & $2.3 \pm 0.1$ \\
\hline $22: 6(n-3)$ & $9,3 \pm 0,5$ & $\begin{array}{c}13,5 \pm 1 \\
1\end{array}$ & $\begin{array}{c}12,4 \pm 0 \\
7\end{array}$ & $\begin{array}{c}14,6 \pm 1 \\
1\end{array}$ & $\begin{array}{l}15.5 \pm 1 . \\
1\end{array}$ \\
\hline Other** & $1,4 \pm 0,1$ & $2,3 \pm 0,1$ & $1,1 \pm 0,1$ & $2,8 \pm 0,1$ & $1.4 \pm 0.1$ \\
\hline \multicolumn{6}{|l|}{ Total } \\
\hline $\begin{array}{l}\text { saturated, } \\
\%\end{array}$ & $\begin{array}{c}33,4 \pm 1 \\
7\end{array}$ & $\begin{array}{c}19,8 \pm 1 \\
1\end{array}$ & $\begin{array}{c}21,2 \pm 1 \\
5\end{array}$ & $\begin{array}{c}33,4 \pm 1 \\
7\end{array}$ & $\begin{array}{l}14.2 \pm 1 . \\
1\end{array}$ \\
\hline $\begin{array}{l}\text { monoenic } \\
\text { \% }\end{array}$ & $\begin{array}{c}27,4 \pm 1 \\
7\end{array}$ & $\begin{array}{c}35,8 \pm 2 \\
1\end{array}$ & $\begin{array}{c}27,1 \pm 1 \\
7\end{array}$ & $\begin{array}{c}27,4 \pm 1 \\
7\end{array}$ & $\begin{array}{l}33.6 \pm 2 . \\
1\end{array}$ \\
\hline $\begin{array}{l}\text { polyenic } \\
, \%\end{array}$ & $\begin{array}{c}39,2 \pm 2 \\
2\end{array}$ & $\begin{array}{c}44,4 \pm 1 \\
8\end{array}$ & $\begin{array}{c}51,7 \pm 3 \\
1\end{array}$ & $\begin{array}{c}39,2 \pm 2 \\
2\end{array}$ & $\begin{array}{l}52.2 \pm 1 . \\
8\end{array}$ \\
\hline$(n-6), \%$ & $\begin{array}{c}16,7 \pm 1 \\
1\end{array}$ & $\begin{array}{c}13,8 \pm 0 \\
7\end{array}$ & $\begin{array}{c}19,6 \pm 1 \\
1\end{array}$ & $\begin{array}{c}16,7 \pm 1 \\
1\end{array}$ & $\begin{array}{l}14.6 \pm 1 . \\
1\end{array}$ \\
\hline$(n-3), \%$ & $\begin{array}{c}22,5 \pm 1 \\
2\end{array}$ & $\begin{array}{c}30,6 \pm 2 \\
0\end{array}$ & $\begin{array}{c}32,1 \pm 2 \\
0\end{array}$ & $\begin{array}{c}22,5 \pm 1 \\
2\end{array}$ & $\begin{array}{l}37.6 \pm 2 . \\
0\end{array}$ \\
\hline$(n-3) /(n-6)$ & 1,35 & 2,22 & 1,64 & 1,35 & 2.57 \\
\hline
\end{tabular}




\begin{tabular}{|l|c|c|c|c|c|}
\hline $\begin{array}{l}18: 3(\mathrm{n}-3) \\
/ 18: 2(\mathrm{n}-6)\end{array}$ & 1,29 & 1,52 & 1,53 & 1,29 & 1.38 \\
\hline
\end{tabular}

Differences in the distribution of fatty acids in the tissues of whitefish of the two reservoirs are indicative.

The content of monoenoic fatty acids (MUFA) in the muscles of the whitefish from lake Lovozero is higher (up to $36.1 \%$ of the total content of fatty acids) than in the whitefish from Umbozero (to $27.4 \%$ ) (Figure 1). It is known that most monoenoic fatty acids are of dietary origin [5], so these differences may be associated with the characteristics of forage of the objects studied: Umbozero is an ultraoligotrophic lake while Lovozero is an oligotrophic one $[6,7,8]$. Oleic acid is dominant among MUFA in all objects tested. It is found that $18: 1$ FA among monoenoic is the most important for the temperature adaptation of fish and is a source of metabolic energy [9, 10].

A higher content of MUFA in the liver (to $44.3 \%$ ) is found in the whitefish from Lovozero lake, this provides for the reduction of metabolism in hepatocytes, associated with the increased biomebrane viscosity of [1].

In the muscles of the immature whitefish from lake Umbozero the content of polyenic fatty acids (PUFA) was higher $(39.1 \%)$ than in the whitefish from Lovozero $(30.1 \%)$. Moreover, the level of PUFA significantly increases (to $51.7 \%$ ) in the mature fish from Umbozero (Figure 2). This is probably due to the features of the temperature regime in the reservoirs. Umbozero is a deep and slightly-warmed lake in contrast to Lovozero lake $[6,7,8]$. It is known that the unsaturation of lipids in organs and tissues increases with decrease in the temperature of fish habitats [11]. As stated by many researchers, the increase in the content of polyenic fatty acids occurs with the increase of physical activity [11, $12,13]$. Thus, the peculiarities of the content of PUFA can be associated with active swimming of the whitefish in cold water of lake Umbozero.

A lower level of polyenic fatty acids in the liver of the whitefish of lake Lovozero (to $24.5 \%$ ) compared to the whitefish from Umbozero $(51.8 \%)$ is defined. Since fatty acids provide necessary fluidity and permeability of the membranes of hepatocytes, this may indicate a change in permeability of biological membranes in the liver of the whitefish from Lovozero, and, as a consequence - the decrease in aerobic metabolism in hepatocytes.

The total content of saturated acids (SFA) in the muscle and liver tissues of the whitefish from Lovozero is above (up to $37.2 \%$ ) than from Umbozero lake due to the dominance, of palmitic acid (Figure 3). The ratio 16:0 FA is known to be crucial in the metabolism of SFA in fish [11]. With age, the level of SFA reduces to $21.2 \%$ in the muscles of the fish from lake Umbozero.

In the gonads of the whitefish females from the two water bodies, the content of saturated fatty acids is low (up to $16.3 \%$ ) compared to the polyenic fatty acids (up to $52.2 \%$ ), this indicates the reduction of the membrane viscosity, which is necessary for optimal entrance of the components inside the oocyte during the process of gonad maturation.

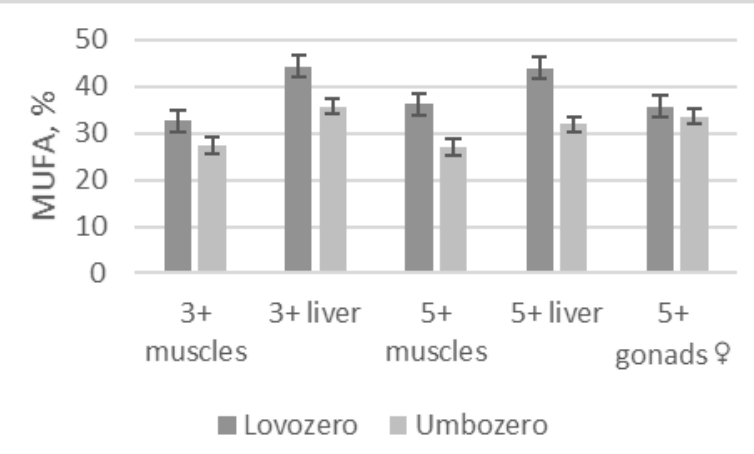

Fig. 1. The content of MUFA in tissues (organs) of whitefish, $\%$.

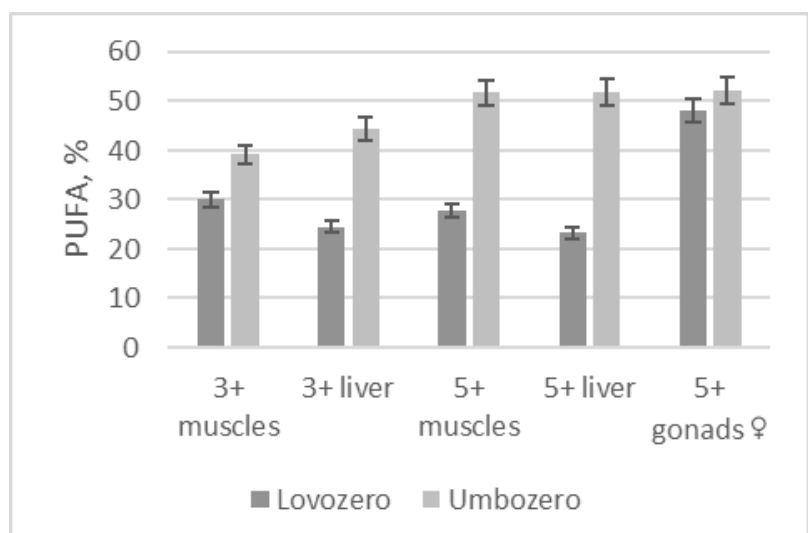

Fig. 2. The content of PUFA in tissues (organs) of whitefish, $\%$.

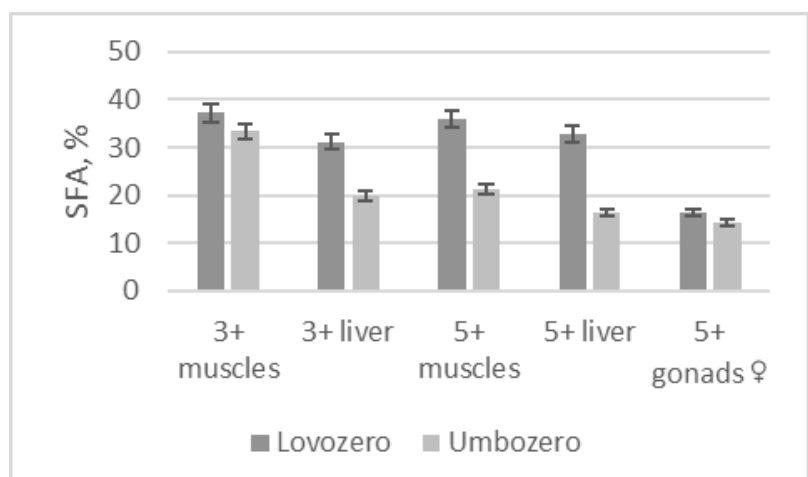

Fig. 3. The content of SFA in tissues (organs) of whitefish, $\%$.

High values of (n-3) polyunsaturated fatty acids and, accordingly, such factors as (n-3)/(n-6) and 18:3(n$3) / 18: 2(n-6)$ for the muscles (1.64 and 1.53 , respectively) and the liver of the mature whitefish from lake Umbozero (2.52 and 1.85) and gonads of the fish from both lakes (tab. 1 and 2) are found. This indicates increased fluidity of biomembranes of the cells and acceleration of metabolism [13].

In the family of (n-3) PUFA eicosapentaenoic (EPA) and docosahexaenoic acids (DHA) were dominant, and among (n-6) polyunsaturated fatty acids was arachidonic, which are essential for fish and must be 
obtained from food [14]. In the muscle and liver of the whitefish from lake Umbozero the content of these acids is higher compared to the whitefish from Lovozero. Increased DHA content in fish muscle is associated with increase in their motor activity $[11,15]$, and it is also known that fatty acid participates in the regulation of physical and chemical state of cell membranes and activity of membrane-bound enzymes [12]. There is a high concentration of eicosapentaenoic and docosahexaenoic acids in the gonads of the female whitefish from both reservoirs, which in case of the embryos is probably associated with their need in fatty acids.

\section{Conclusion}

1. The content of monoenoic fatty acids in the muscle tissue of the whitefish from lake Lovozero is higher (up to $36.1 \%$ ) than that of the whitefish from Umbozero (up to $27.4 \%$ ), which is probably due to the features of the food base of the objects studied.

2 . In the muscles of the immature whitefish from lake Umbozero, a higher level of polyenic fatty acids (39.1 $\%$ ) was found compared to the whitefish from Lovozero lake $(30.1 \%)$. Moreover, the content of PUFA increases significantly in the whitefish from Umbozeroto to the mature state, probably, associated with the features of the temperature regime in the water bodies and various rates of fish motor activity.

3. A lower level of PUFA in the liver of the whitefish from Lovozero (up to $24.5 \%$ ) compared to the whitefish from Umbozero $(51.8 \%)$ may indicate a metabolic decrease in hepatocytes.

4. In the gonads of the whitefish females from the water bodies studied, the content of saturated fatty acids is low (up to $16.3 \%$ ) compared to polyenic fatty acids (up to $52.2 \%$ ), which is characteristic for a decrease in the viscosity of oocyte membranes.

5. Essential fatty acids, especially (n-3) PUFA, prevail in the muscle tissue and liver of the whitefish from lake Umbozero and in fish gonads from both reservoirs. The increased content of docosahexaenoic acid in the muscle tissue of fish is associated with the increase in their motor activity, DHA is involved in the regulation of the physicochemical state of cell membranes.

6. The primary role of fatty acids in the whitefish organs and tissues is participation in adaptive mechanisms developed as a result of adaptation of this species to various environments.

\section{References}

1. L. A. Mishanina (Pohol'chenko) Tkanevye belki i lipidy u dikoj i zavodskoj molodi atlanticheskogo lososya Salmo salar L. Kol'skogo poluostrova. Dis. ... kand. biolog. nauk. (Petrozavodsk, 2011)

2. M. Kejts, Tekhnika lipidologii (Moscow, Mir, 1975)

3. E. G. Cyganov, Metod pryamogo metilirovaniya lipidov posle tonkoslojnoj hromatografii bez elyuirovaniya s silikagelem, Laboratornoe delo 8, 490-493 (1971)

4. G. F. Lakin, Biometriya: uchebnoe posobie dlya biol. spec. vuzov (Moscow, Vysshaya shkola, 1990)

5 M. Graeve, M. Lundberg, M. Boer, G. Kattner, H. Hop, S. Falk-Petersen, The fate of dietary lipids in the Arctic ctenophore Mertensia ovum (Fabricius, 1780), Marine Biology 153, 643-651 (2008)

6 V. M. Hromova, Ezhegodnik sostoyaniya ekosistem poverhnostnyh vod Rossii po gidrobiologicheskim pokazatelyam za 2014 god (Moskva, FGBU «Institut global'nogo klimata i ekologii Federal'noj sluzhby po gidrometeorologii i monitoringu okruzhayushchej sredy i RAN», 2015)

7 L. A. Mishanina, Aminokislotnyj sostav myshechnoj tkani siga obyknovennogo Coregonus lavaretus L. Kol'skogo poluostrova, Vestnik MGTU 21(2), 295-302 (2018)

8 L. Mishanina, A. Malaeva Lipid composition of the tissues of Coregonus lavaretus L. of the Kola Peninsula, KnE Life Sciences, 2020, 325-332 (2020)

9 B. Antonny, S. Vanni, H. Shindou, T. Ferreira, From zero to six double bonds: phospholipid unsaturation and organelle function, Trends in Cell Biology 25(7), 427-436 (2015)

10 M. I. Shatunovskij, Ekologicheskie zakonomernosti obmena veshchestv morskih ryb (Moscow, Nauka, 1980)

11 E. M. Kreps Lipidy kletochnyh membran (Leningrad, Nauka, 1981)

12 G. E. Shul'man, K. K. Yakovleva, Geksaenovaya kislota i estestvennaya podvizhnost' ryb, Zhurnal obshchej biologii 44(4), 529-540 (1983)

13. L. P. Smirnov, V.V. Bogdan, Lipidy v fiziologobiohimicheskih adaptaciyah ektotermnyh organizmov $k$ abioticheskim i bioticheskim faktoram sredy (Petrozavodsk, Nauka, 2007)

14. S. A. Zabelinskij, M. A. Chebotareva, H. B. Brovcina, A. I. Krivchenko, Ob «adaptivnoj signalizacii» sostava konformacionnyh sostoyanij zhirnyh kislot $\mathrm{v}$ membrannyh lipidah zhabr ryb, Zhurnal evolyucionnoj biohimii $i$ fiziologii 31(1), 29-37 (1995)

15. G. E. Shul'man, T. V. Yuneva, Rol' dokozageksaenovoj kisloty $\mathrm{V}$ adaptaciyah ryb (obzor), Ekologicheskaya fiziologiya $i$ biohimiya vodnyh zhivotnyh 26(4), 43-51 (1990) 